Article

\title{
Iron Chelate Improves Rooting in Indole-3-Butyric Acid-Treated Rosemary (Rosmarinus officinalis) Stem Cuttings
}

\author{
Zeinab Izadi ${ }^{1, *}$, Abdolhossein Rezaei Nejad ${ }^{1}$ and Javier Abadía ${ }^{2, *(D)}$ \\ 1 Department of Horticultural Sciences, Faculty of Agriculture, Lorestan University, P.O. Box 465, \\ Khorramabad 68151-44316, Iran; rezaeinejad.h@lu.ac.ir \\ 2 Department of Plant Nutrition, Estación Experimental de Aula Dei (EEAD-CSIC), \\ Av. Montañana 10005, 50059 Zaragoza, Spain \\ * Correspondence: izadi.ze@fa.lu.ac.ir (Z.I.); jabadia@eead.csic.es (J.A.)
}

check for updates

Citation: Izadi, Z.; Rezaei Nejad, A.; Abadía, J. Iron Chelate Improves Rooting in Indole-3-Butyric Acid-Treated Rosemary (Rosmarinus officinalis) Stem Cuttings. Agriculture 2022, 12, 210. https://doi.org/

10.3390 /agriculture12020210

Academic Editors: Mario Licata, Antonella Maria Maggio,

Salvatore La Bella and

Teresa Tuttolomondo

Received: 10 December 2021

Accepted: 30 January 2022

Published: 1 February 2022

Publisher's Note: MDPI stays neutral with regard to jurisdictional claims in published maps and institutional affiliations.

Copyright: () 2022 by the authors Licensee MDPI, Basel, Switzerland. This article is an open access article distributed under the terms and conditions of the Creative Commons Attribution (CC BY) license (https:// creativecommons.org/licenses/by/ $4.0 /)$.

\begin{abstract}
Adventitious root formation in stem cuttings is affected by exogenous and endogenous factors. The study assessed the effect of Fe(III)-EDDHA (ethylenediamine- $N, N$-bis 2-hydroxyphenyl acetic acid) on the rooting of 4 indol-3-butyric acid (IBA)-treated hardwood cuttings of the aromatic and medicinal species Rosmarinus officinalis. Cuttings treated with 0, 1000, 2000 or $3000 \mathrm{mg} \mathrm{L}^{-1}$ IBA were placed in pots filled with sand:perlite mixture and irrigated daily with nutrient solution pH 5.8, containing 0, 5, 10 or $20 \mu \mathrm{M}$ Fe(III)-EDDHA. Ten days later, the number of new emerging roots were recorded. After 20 days, leaf photosynthetic pigments and morphological traits, including root number, fresh (FW) and dry weight (DW), shoot FW and DW, mean length of the longest roots, number of new shoots and new growth in old shoots, were measured. Finally, plants were transplanted to pots filled with a sand:soil mixture and survival was measured after 10 days. Results indicate that Fe application promotes root emergence and improves root and shoot biomass, leaf photosynthetic pigment concentrations and survival percentage. This indicates that using low concentrations of Fe(III)-EDDHA (5-20 $\mu \mathrm{M})$ in the growth medium could be a good management strategy to facilitate the production of vigorous $R$. officinalis plants from hardwood cuttings.
\end{abstract}

Keywords: rooting; hardwood cuttings; iron chelates

\section{Introduction}

Adventitious root formation in plant cuttings is influenced by a large set of exogenous and endogenous factors [1]. Root initiation involves de-differentiation of specific cells leading to the formation of the root meristems [1]. Endogenous factors that could act as rooting co-factors and auxin transport modulators are transferred from the stock plants to the propagules [2]. These include auxin and carbohydrates [3], mineral nutrients [4] and other metabolites, including phenolic compounds [5].

Among the exogenous rooting factors, the auxin IBA (indole-3-butyric acid) is widely used to stimulate rooting processes in cuttings, because of its high ability to promote root initiation. This effect of IBA is thought to be due to its conversion in the plant tissue to indole-3-acetic acid (IAA), which is needed for the rooting process. Endogenous IAA can be readily oxidized in plants by peroxidase, but IBA is quite stable and is only slowly transported from the site of application at the base of the cuttings, resulting in a localized IAA production [6]. Exogenous IBA application has been shown to have positive rooting effects in many woody plant species, including Citrus medica [7], R. damascena [8], Hibiscus rosa-sinensis [9], Olea europaea [10,11], Zizyphus jujuba [12], Tilia rubra [13], Eucaliptus spp. [14,15], Sterculia foetida [16], Castanea spp. [17] and Populus [18]. For instance, in Cinnamomum bodinieri, exogenous IBA was shown to modify the auxin signaling pathway and carbohydrate metabolism, improve the formation of lateral root initiation site and root cell elongation, and enhance d-glucose synthesis as well as sucrose and starch utilization [19]. 
Other exogenous factors involved in rooting are mineral nutrients, which are involved in many metabolic processes associated with differentiation and root meristem formation, which is essential for root initiation [1]. Transcriptome analysis of adventitious root formation in Petunia $\times$ hybrida revealed an increase, starting from the initiation phase, in the expression of 18 genes involved in the uptake and assimilation of N, P, K, S, Fe and Zn [4]. For instance, within this period a high transcript abundance was observed for a plasma membrane H-ATPase, which may energize nutrient uptake [4]. The mineral nutrient composition of the cuttings, especially regarding micronutrients such as $\mathrm{Fe}, \mathrm{Zn}, \mathrm{Mn}$ and $\mathrm{B}$, plays a key role in controlling root morphogenesis. Iron and Mn are cofactors and structural components of peroxidase and can therefore directly affect IAA catabolism [20]. Iron is an essential micronutrient for plants, which plays vital roles in many metabolic processes in plants, including photosynthesis, respiration and $\mathrm{N}_{2}$ fixation [21]. Additionally, auxin is involved in the root responses to Fe deficiency [21-23]. A boosting effect of mineral nutrients (including Fe) on propagation of plant cuttings has also been reported in different studies [24,25]. In hardwood cuttings from Fe-deficient peach trees, the application of Fe compounds significantly reduced chlorotic symptoms and improved rooting [26].

Rosemary (Rosmarinus officinalis) is a xerophytic, aromatic, evergreen shrub widely used for food and as an ornamental species in gardens. Because of its hardiness under environmental stress, it is also used to protect against soil erosion and is planted in firedamaged areas. Rosemary is a medicinal species that contains polyphenols, resulting in a number of pharmacological effects, including antioxidant, antitumor, antidiabetic and antibacterial ones [27-29]. Rosemary plants can be propagated by seed and stem cuttings, but propagation from seeds is rarely used, because of the long times needed for blooming and germination and the low germination rates (10-20\%) [30,31]. Rooting of $R$. officinalis cuttings is facilitated by using hormone treatments [32,33], and different approaches are being used to further improve the rooting ability, with the aim to reduce costs and allow for mass production. For instance, it has been recently shown that using blue light induces an upregulation of auxin signaling and leads to better root formation [30].

The aim of this work was to assess the hypothesis that Fe supplementation in the form of Fe(III)-chelate can promote rooting in stem cuttings of the medicinal and aromatic plant $R$. officinalis treated with IBA. Four concentrations each of Fe and IBA were used and shoot and root biomass as well as rooting parameters were studied.

\section{Materials and Methods}

\subsection{Greenhouse and Propagation Conditions}

This study was carried out in March 2018, in an experimental greenhouse of the Lorestan University, Khorramabad, Lorestan Province, in the western part of Iran $\left(33^{\circ} 45^{\prime} \mathrm{N} 48^{\circ} 26^{\prime} \mathrm{E}\right)$. The greenhouse was north-south oriented, the mean temperature and relative humidity were maintained at $22 / 28^{\circ} \mathrm{C}$ (night/day) and 55-75\%, respectively, and the light intensity was approximately $500 \pm 100 \mu \mathrm{mol}$ quanta $\mathrm{m}^{-2} \mathrm{~s}^{-1}$ (photosynthetically active photon flux density).

\subsection{Plant Material and Growth Conditions}

Cuttings were taken from vigorous and healthy bushes of $R$. officinalis, 10 years old, growing in the Faculty of Agriculture, Lorestan University (originated from cuttings obtained at the National Botanical Garden of Iran, Tehran). Cuttings consisted of hardwood branches (including the apical meristem), excised approximately $1 \mathrm{~cm}$ below a leaf node, at least $15 \mathrm{~cm}$ in length and with 7-8 nodes. In each cutting, leaves in the lower $5 \mathrm{~cm}$ were removed, and the basal $1 \mathrm{~cm}$ was dipped for $5 \mathrm{~s}$ [34] in a solution containing different IBA (CAS number 133-32-4) concentrations $\left(0,1000,2000\right.$ or $3000 \mathrm{mg} \mathrm{IBA} \mathrm{L}^{-1}-0,4.9,9.8$ or $14.8 \mathrm{mM}$, respectively; these concentrations were thereafter called 0, 1000, 2000 and 3000 IBA). Cuttings were then placed in pots ( $28.0 \mathrm{~cm}$ height and $25.5 \mathrm{~cm}$ in diameter; ten cuttings per pot) filled with a sand:perlite (1:1, w:w) mixture, and irrigated daily with a nutrient solution containing (in $\mathrm{mM}$ ) $0.1 \mathrm{KH}_{2} \mathrm{PO}_{4}$, $0.1 \mathrm{MgSO}_{4}, 0.25 \mathrm{CaCl}_{2}$ and $2 \mathrm{NH}_{4} \mathrm{NO}_{3}$, and (in $\left.\mu \mathrm{M}\right) 50 \mathrm{H}_{3} \mathrm{BO}_{3}$ and $5 \mathrm{MnSO}_{4}$; the solution also 
contained $1 \mathrm{mM}$ MES (2-(N-morpholino)ethanesulfonic acid), and the $\mathrm{pH}$ was 5.8. The nutrient solution was supplemented with $0,5,10$ or $20 \mu \mathrm{M}$ Fe(III)-EDDHA (ethylenediamine- $N, N$-bis 2-hydroxyphenyl acetic acid; Sequestrene $138 \mathrm{Fe}, 6 \%$ chelated Fe, Syngenta, Basel, Switzerland). These Fe concentrations are thereafter called 0, 5, 10 and 20 Fe. Pictures of the plants are shown in Figure S1 in the Supplementary File. Pots were covered with a clear polyethylene sheet to keep the medium moist. Pots were irrigated daily with the same nutrient solutions (1 L per pot), with the excess being drained. After 10 days new roots had emerged, and after 20 days new shoot tissue and leaves had developed. At that date, three plants per treatment were transferred to pots filled with a sand:soil mixture $(1: 2, \mathrm{w}: \mathrm{w})$ and grown for 10 more days. Four replications (pots) were used for all treatments.

\subsection{Plant Morphological Traits}

Ten days after the root induction treatment, three cuttings were taken from each pot (a total of 12 cuttings per treatment) and used to count the number of newly developed roots. Twenty days after rooting induction, four plants from each pot were used to determine morphological traits, including root number, fresh (FW) and dry weight (DW), shoot FW and DW, mean length of the longest roots, number of new shoots and new growth in old shoots (a total of 16 cuttings were considered per treatment). The three remaining plants from each pot were transferred to the sand:soil mixture, and plant survival was recorded after 10 days.

\subsection{Pigment Analysis}

Chlorophyll a ( Chl a), Chl b, total $\mathrm{Chl}(\mathrm{Chl} \mathrm{a}+\mathrm{b})$ and carotenoid (Car) concentrations were determined 20 days after the rooting induction treatment, in leaves of the same plants considered for analysis of morphological parameters. Leaf tissue $(0.1 \mathrm{~g} \mathrm{FW})$ was collected from young, fully expanded leaves pooled from four plants in each pot, ground in liquid $\mathrm{N}_{2}$ with mortar and pestle, homogenized with $10 \mathrm{~mL} 100 \%$ acetone, centrifuged for $15 \mathrm{~min}$ at $4000 \mathrm{rpm}$, and the supernatant collected. The absorbance of the extracts was measured as 470, 662 and $645 \mathrm{~nm}$ using a spectrophotometer (Mapada UV-1800, Shanghai, P.R. China), and the leaf pigment concentrations were calculated as follows: $\mathrm{Chl} \mathrm{a}=11.24 \times \mathrm{A}_{662}-2.04 \times \mathrm{A}_{645} ; \mathrm{Chl} \mathrm{b}=20.13 \times \mathrm{A}_{645}-4.19 \times \mathrm{A}_{662} ; \mathrm{Chl} \mathrm{a}+\mathrm{b}=\mathrm{Chl}$ $\mathrm{a}+\mathrm{Chl} \mathrm{b} ; \mathrm{Car}=\left(1000 \times \mathrm{A}_{470}-1.90 \mathrm{Chl} \mathrm{a}-63.14 \mathrm{Chl} \mathrm{b}\right) / 214$ [35]. Leaf pigments were expressed as $\left(\mathrm{mg} \mathrm{g} \mathrm{FW}^{-1}\right)$.

\subsection{Statistical Analysis}

The experiment was carried out with a completely randomized design with four replications per IBA $\times$ Fe treatment (16 treatments in total, four IBA and four Fe concentrations; 64 pots in total). All data were subjected to analysis of variance (SAS 9.1.3, SAS Institute Inc., Cary, NC, USA), and normality and homogeneity tested. Post hoc multiple comparison of means corresponding to the different treatments was carried out (at $p \leq 0.05$ ) using a LSD test; comparisons were carried out for the Fe treatments in a given IBA treatment, and also for the IBA treatments in a given Fe treatment (significance letters are shown in all Figures in lower case and capitals, respectively). Values shown are means of four replications-pots-each averaging values from three and four plants per pot in the cases of root number and the rest of parameters, respectively.

\section{Results}

Both factors that were used, IBA and Fe doses, had statistically significant effects on all parameters analyzed, with the only exception of Car content for $\mathrm{Fe}$, and the interaction IBA $\times$ Fe was also significant (Table S1 in the Supplementary File).

\subsection{Application of Fe Enhance the Rooting Performance in IBA-Treated Cuttings}

Ten days after the IBA/Fe treatments, the percentage of rooting was between 0 and 100\% (Figure 1). At that time, the control 0 IBA/0 Fe cuttings did not show any root- 
ing signs, whereas cuttings under the 2000-3000 IBA/5 Fe, 1000-3000 IBA/10 Fe and 1000-3000 IBA/20 Fe treatments showed 100\% rooting. The 1000-3000 IBA/0 Fe, 0-1000 IBA/ $5 \mathrm{Fe}, 0 \mathrm{IBA} / 10 \mathrm{Fe}$ and $0 \mathrm{IBA} / 20$ Fe treatments led to intermediate percentages of rooting. In the absence of Fe, treatments with 1000-3000 IBA increased this parameter.

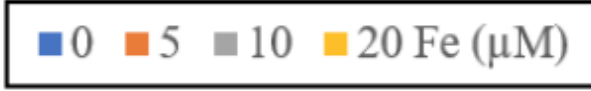

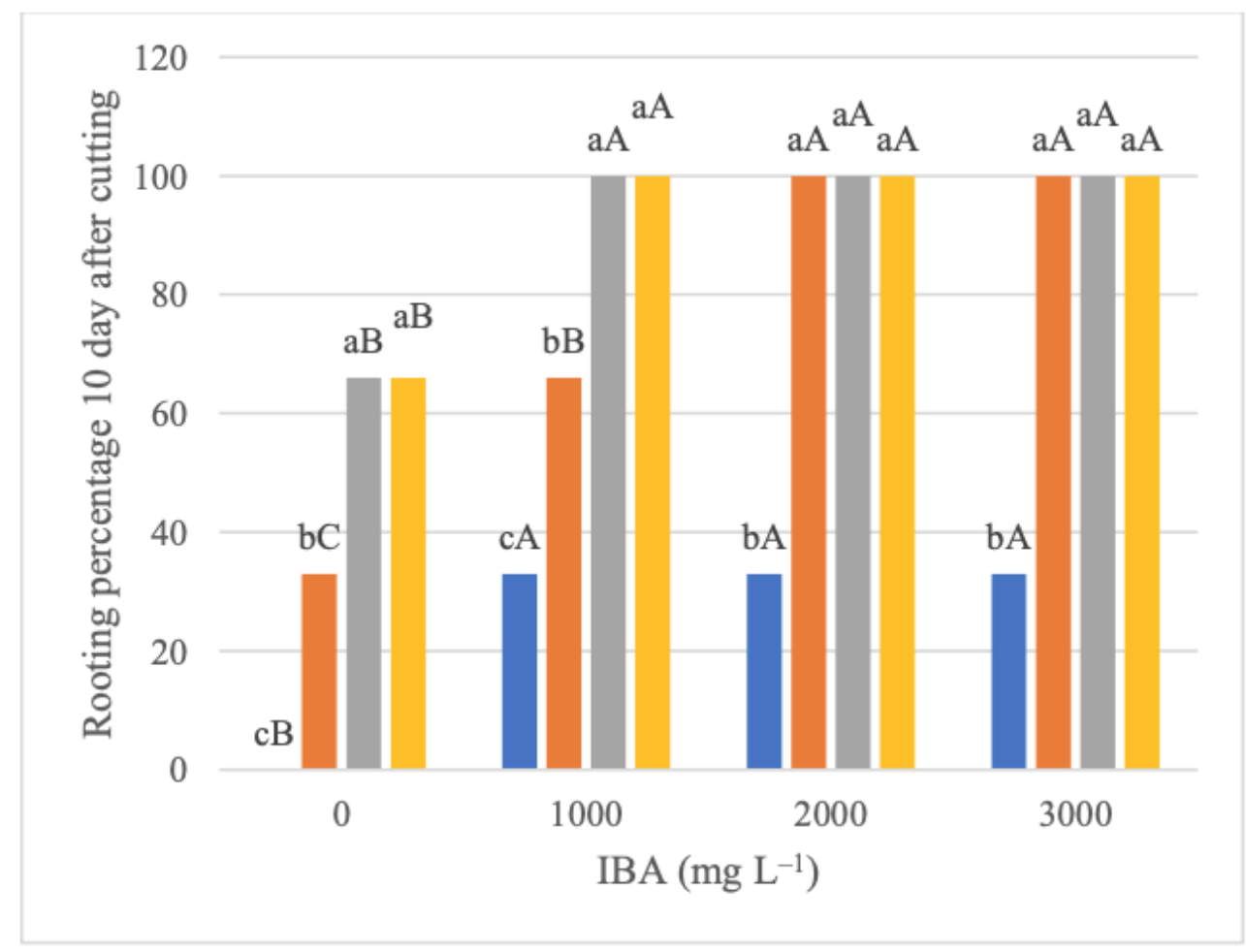

Figure 1. Percentages of rooting 10 days after the rooting induction treatments in Rosmarinus officinalis stem cuttings. Cuttings were treated with different concentrations of IBA $(0,1000,2000$ and $\left.3000 \mathrm{mg} \mathrm{L}^{-1}\right)$ at the start of the experiment and then grown with different concentrations of $\mathrm{Fe}$ $(0,5,10$ and $20 \mu \mathrm{M})$. Values shown are means \pm SE $(n=4$ pots). Letters above the columns indicate significant differences at $p \leq 0.05$ for the Fe treatments in a given IBA treatment (in lower case) and for the IBA treatments in a given Fe treatment (in capitals).

\subsection{Application of Fe Increase Biomass in IBA-Treated Root Cuttings}

Twenty days after the start of the experiment, the root FW was between 0.19 and $0.66 \mathrm{~g}$ per plant, depending on the treatment (Figure 2A). The highest values were observed in some treatments including IBA and Fe (3000 IBA/5 Fe, $2000 \mathrm{IBA} / 10 \mathrm{Fe}$ and $1000 \mathrm{IBA} / 20 \mathrm{Fe}$ ), and the lowest in the $0 \mathrm{IBA} / 0$ Fe and the $0 \mathrm{IBA} / 5$ Fe treatments, whereas other treatments led to intermediate values. The 10-20 Fe treatments increased root FW in cuttings not treated with IBA. On the other hand, in the absence of Fe treatments with 1000-3000 IBA increased this parameter.

The root DW was between 0.013 and $0.077 \mathrm{~g}$ per plant depending on the treatments (Figure 2B). The highest values were observed in some treatments including IBA and Fe (1000-3000 IBA/5 Fe, 1000-2000 IBA/10 Fe and 1000-3000 IBA/20 Fe), and the lowest in the 0 IBA/ 0 Fe control, whereas other treatments led to intermediate values. All treatments with Fe increased root DW in cuttings not treated with IBA. In the absence of Fe, treatments with 1000-3000 IBA increased this parameter. 


\section{घ0 $\quad 5 \quad \square 10 \quad \square 20 \mathrm{Fe}(\mu \mathrm{M})$}

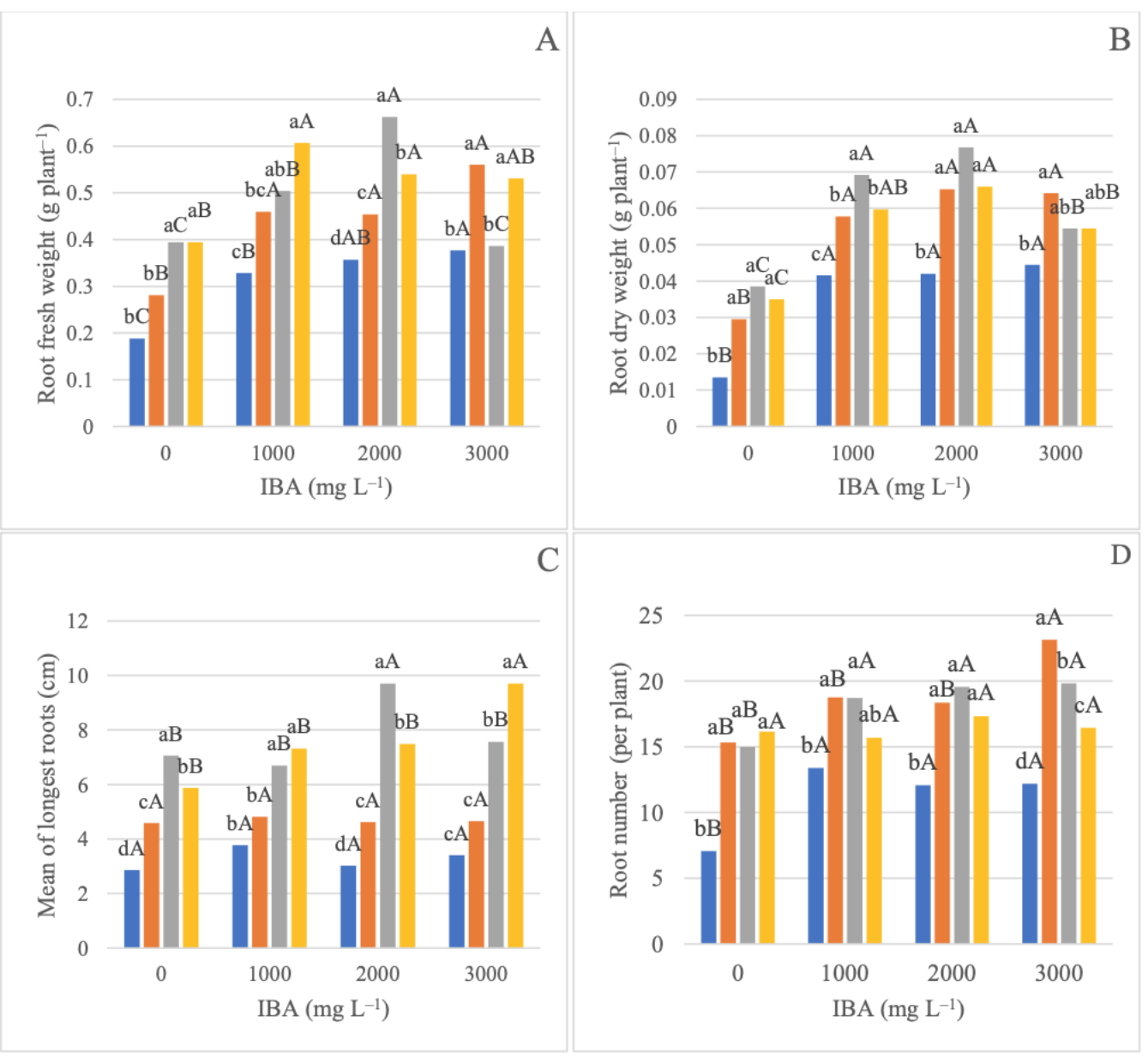

Figure 2. Root parameters 20 days after the rooting induction treatments in Rosmarinus officinalis stem cuttings. Cuttings were treated with different concentrations of IBA $\left(0,1000,2000\right.$ and $\left.3000 \mathrm{mg} \mathrm{L}^{-1}\right)$ at the start of the experiment and then grown with different concentrations of $\mathrm{Fe}(0,5,10$ and $20 \mu \mathrm{M})$. Root fresh weight ((A), in g plant $\left.^{-1}\right)$, root dry weight ((B), in $\left.\mathrm{g} \mathrm{plant}^{-1}\right)$, mean of longest roots $((\mathbf{C})$, in $\mathrm{cm}$ ) and root number per plant (D). Values shown are means \pm SE ( $n=4$ pots). Letters above the columns indicate significant differences at $p \leq 0.05$ for the Fe treatments in a given IBA treatment (in lower case) and for the IBA treatments in a given Fe treatment (in capitals).

\subsection{Application of Fe Increase Root Length and Number in IBA-Treated Root Cuttings}

The mean length of the longest roots was in the range $2.9-9.7 \mathrm{~cm}$, and it was markedly affected by the IBA/Fe regimes (Figure $2 \mathrm{C}$ ). The highest value was observed in the $2000 \mathrm{IBA} / 10 \mathrm{Fe}$ and $3000 \mathrm{IBA} / 20 \mathrm{Fe}$, and the lowest in the 0 Fe treatments. All treatments with Fe increased this parameter in cuttings not treated with IBA, whereas in the absence of Fe treatments with IBA did not have any effect.

The number of roots per plant was in the range 7-23, and it was markedly affected by the IBA/Fe regimes (Figure 2D). The highest value was observed in the $3000 \mathrm{IBA} / 5 \mathrm{Fe}$ treatment, and the lowest in the $0 \mathrm{IBA} / 0 \mathrm{Fe}$. All treatments with Fe increased root number in cuttings not treated with IBA. In the absence of Fe, treatments with 1000-3000 IBA increased root number.

\subsection{Application of Fe-Chelate Causes Positive Changes in Shoot Parameters by IBA}

Shoot FW was between 2.1 and 4.7 g per plant depending to the treatment (Figure 3A). The highest values were observed in the 1000-3000 IBA/5 Fe, 1000-2000 IBA/10 Fe and 1000 IBA/ 20 Fe treatments, and the lowest in the 0 IBA/ 0 Fe control one. All treatments 
with Fe increased shoot FW in cuttings not treated with IBA. Treatments with 1000-3000 IBA increased this parameter in the absence of Fe.

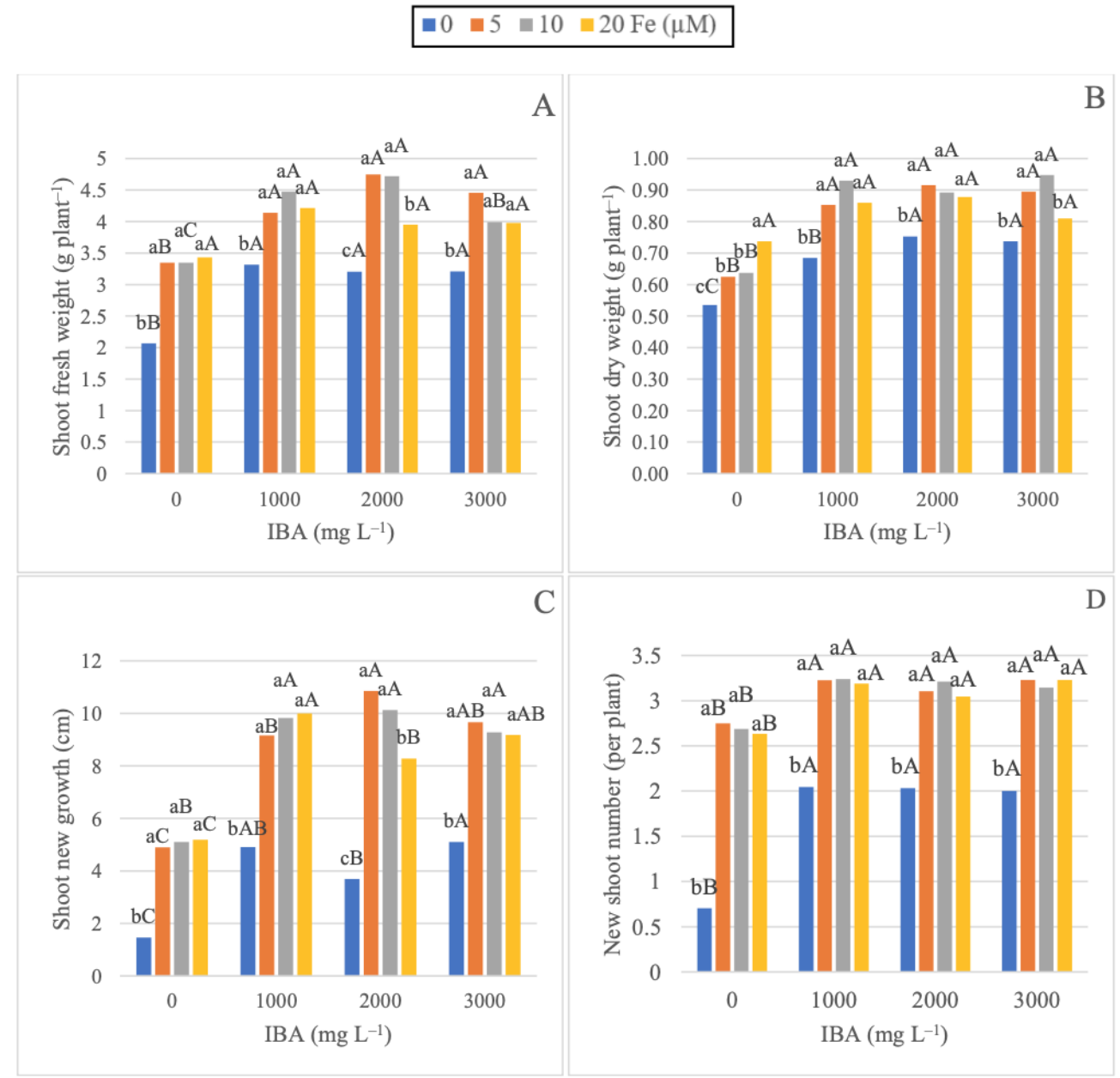

Figure 3. Shoot parameters 20 days after the rooting induction treatments in Rosmarinus officinalis stem cuttings. Cuttings were treated with different concentrations of IBA $\left(0,1000,2000\right.$ and $\left.3000 \mathrm{mg} \mathrm{L}^{-1}\right)$ at the start of the experiment and then grown with different concentrations of $\mathrm{Fe}(0,5,10$ and $20 \mu \mathrm{M})$. Shoot fresh weight $\left((\mathbf{A})\right.$, in $\left.\mathrm{g} \mathrm{plant}^{-1}\right)$, shoot dry weight $(\mathbf{B})$, in $\left.\mathrm{g} \mathrm{plant}^{-1}\right)$, shoot new growth $((\mathbf{C})$, in $\mathrm{cm})$, and new shoot number per plant (D). Values shown are means $\pm S E$ ( $n=4$ pots). Letters above the columns indicate significant differences at $p \leq 0.05$ for the Fe treatments in a given IBA treatment (in lower case) and for the IBA treatments in a given Fe treatment (in capitals).

Total shoot DW was between 0.54 and 0.95 g per plant, and values were markedly affected by the Fe regime (Figure 3B). The highest values were observed in the 1000-3000 IBA/5-10 Fe and 1000-2000 IBA/20 Fe treatments and the lowest in the 0 IBA/0 Fe control. Treatments with Fe increased shoot DW in cuttings not treated with IBA, and in the absence of Fe treatments with 1000-3000 IBA increased this parameter.

Shoot new growth was between 1.5 and $10.9 \mathrm{~cm}$ depending on the treatment (Figure 3C). The highest values were observed in the 1000-3000 IBA/5-10 Fe and 1000 and 3000 IBA/20 Fe treatments, and the lowest in the 0 IBA/ 0 Fe control one. Treatments with Fe increased shoot new growth in cuttings not treated with IBA, whereas in the absence of Fe treatments with 1000-3000 IBA increased this parameter.

The number of new shoots per plant was in the range 0.7-3.2, and it was affected by the IBA/Fe regimes (Figure 3D). The highest values were observed in the 1000-3000 IBA/5-20 Fe and the lowest in the $0 \mathrm{IBA} / 0$ Fe control one. All treatments with Fe increased the number of 
new shoots in cuttings not treated with IBA, and treatment with 1000-3000 IBA increased this parameter in the absence of Fe.

\subsection{Fe-Chelate Increase Leaf Photosynthetic Pigment Concentration of Cuttings}

The concentrations of $\mathrm{Chl} \mathrm{a,} \mathrm{Chl} \mathrm{b,} \mathrm{total} \mathrm{Chl}$ and Car were in the ranges 4.0-9.7, 1.1-6.0, $5.2-15.2$ and $0.7-2.5 \mathrm{mg} \mathrm{g} \mathrm{FW}^{-1}$, respectively, and values were markedly affected by the IBA/Fe regimes (Figure 4). The highest total Chl was observed in the 2000-3000 IBA/10 Fe and 1000-3000 IBA/20 Fe treatments, the highest Car value was in the $1000 \mathrm{IBA} / 20 \mathrm{Fe}$ treatment, and the minimum value for all pigments were observed in the $0 \mathrm{Fe}$ treatments. In cuttings not treated with IBA, all treatments with Fe increased the level of Chls, and treatments with 10-20 Fe increased total Car. On the other hand, in the absence of Fe treatments with IBA did not cause any change in the leaf concentration of photosynthetic pigments.

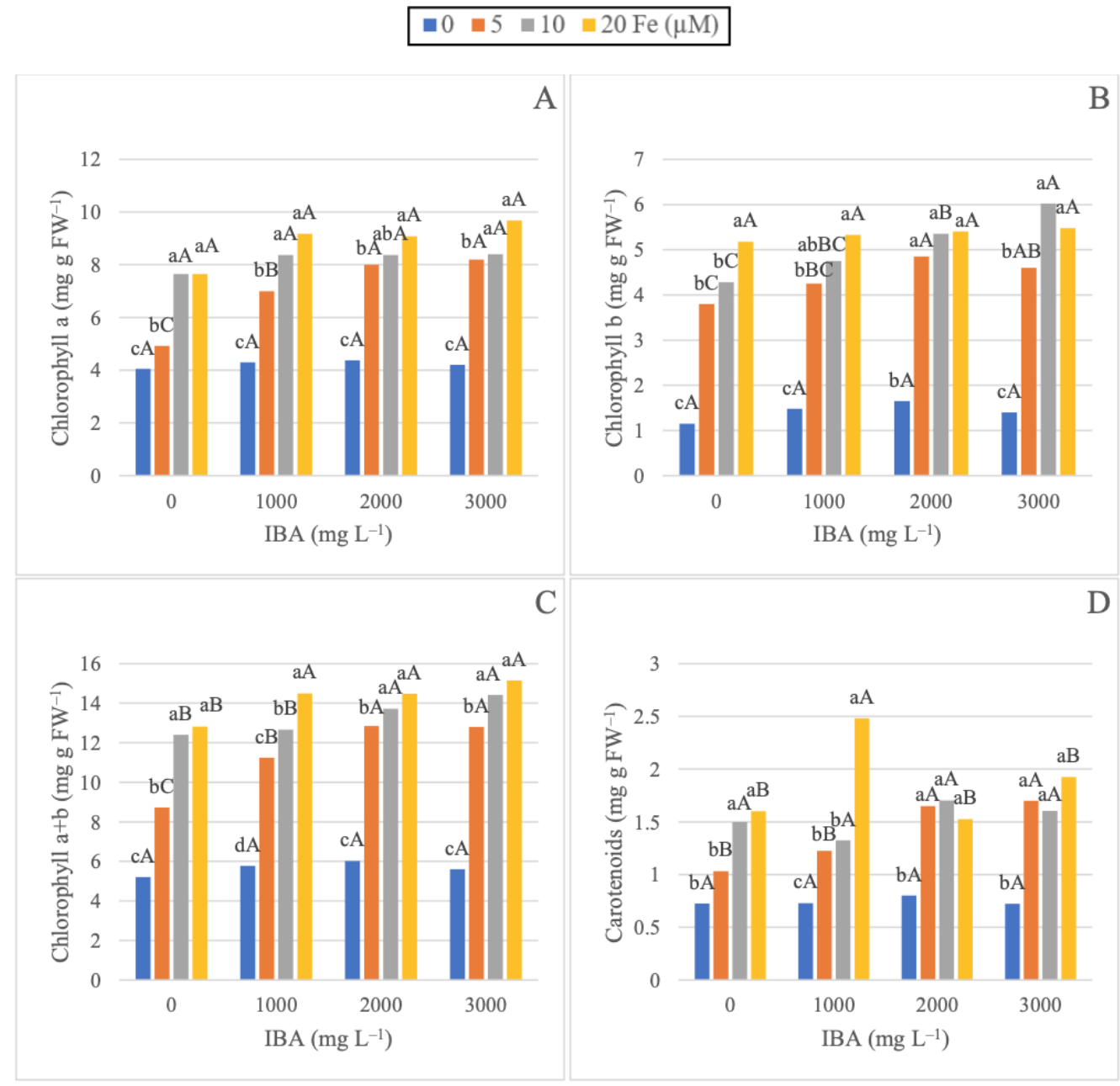

Figure 4. Leaf photosynthetic pigment concentrations 20 days after the rooting induction treatments in Rosmarinus officinalis stem cuttings. Cuttings were treated with different concentrations of IBA $\left(0,1000,2000\right.$ and $\left.3000 \mathrm{mg} \mathrm{L}^{-1}\right)$ at the start of the experiment and then grown with different concentrations of Fe $(0,5,10$ and $20 \mu \mathrm{M})$. Chlorophyll a (A), chlorophyll b (B), total chlorophyll (C), and carotenoid (D) concentrations. Values shown are means \pm SE ( $n=4$ pots). Letters above the columns indicate significant differences at $p \leq 0.05$ for the Fe treatments in a given IBA treatment (in lower case) and for the IBA treatments in a given Fe treatment (in capitals).

\subsection{Cutting Survival Percentage Increased by Applying IBA and Fe-Chelate Simultaneously}

Ten days after transfer to the sand:soil substrate, cutting survival was between 35.3 and $89.3 \%$, and values were markedly affected by the IBA/Fe regimes (Figure 5). The highest 
values were observed in the 1000-3000 IBA/5-20 Fe and the lowest in the 0 IBA/0 Fe control one. All treatments with Fe increased survival significantly in cuttings not treated with IBA. In the absence of Fe, treatments including 1000-3000 IBA increased survival.

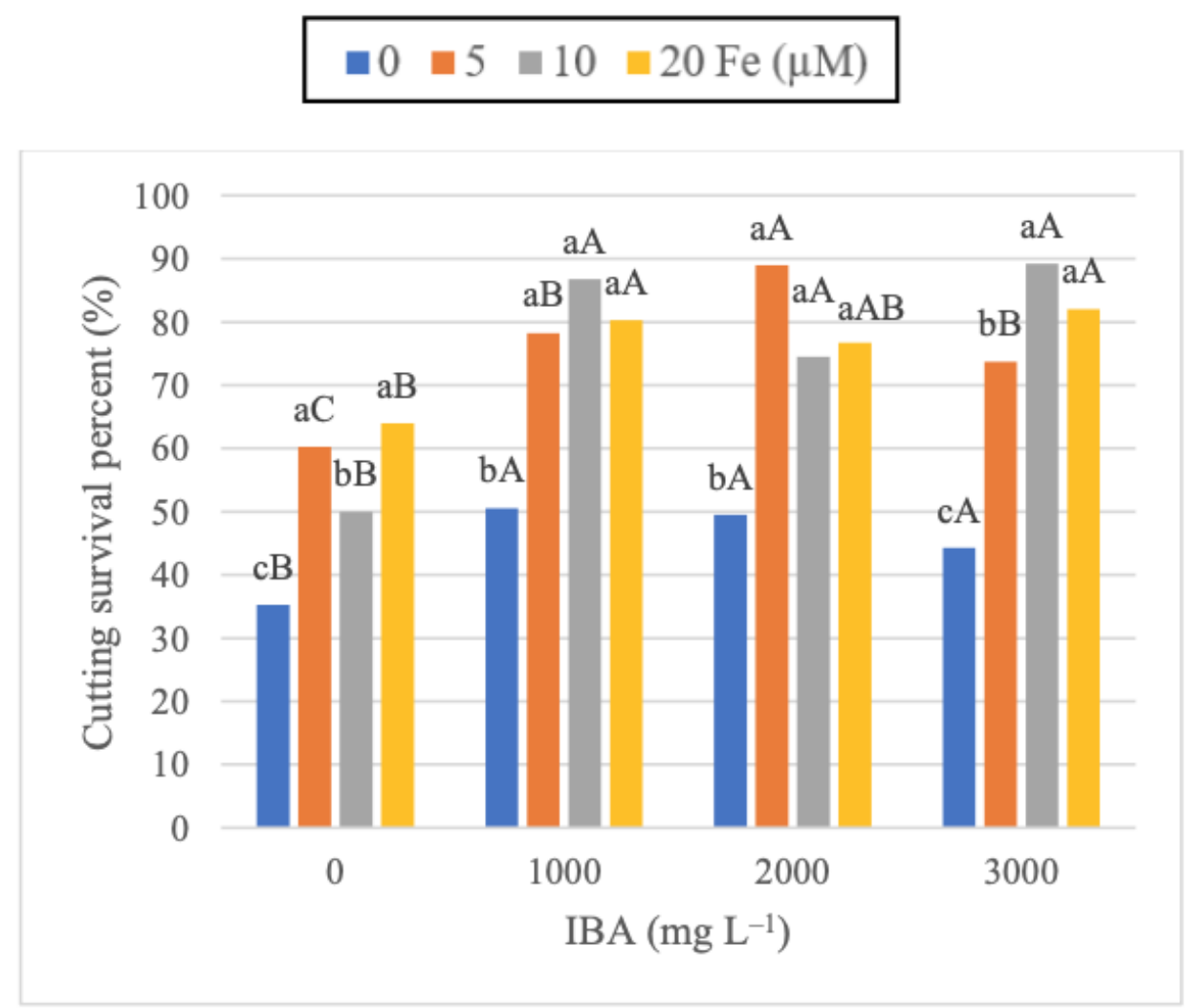

Figure 5. Survival (in \%) of Rosmarinus officinalis stem cuttings 10 days after transfer to a sand:soil mixture. Cuttings were treated with different concentrations of IBA $\left(0,1000,2000\right.$ and $\left.3000 \mathrm{mg} \mathrm{L}^{-1}\right)$ at the start of the experiment, then grown for 20 days with different concentrations of $\mathrm{Fe}(0,5,10$ and $20 \mu \mathrm{M})$ and finally transplanted to the sand:soil mixture. Values shown are means $\pm \mathrm{SE}$ ( $n=4$ pots). Letters above the columns indicate significant differences at $p \leq 0.05$ for the Fe treatments in a given IBA treatment (in lower case) and for the IBA treatments in a given Fe treatment (in capitals).

\section{Discussion}

Results confirm that the application of IBA improves rooting in R. officinalis cuttings, in line with previous results obtained in this plant species [30-33], as well as in many other woody plants [7-18]. Data shown here indicate that when Fe supplementation is not used, an IBA concentration of $1000 \mathrm{mg} \mathrm{L}^{-1}$ appears to be adequate for $R$. officinalis, since higher IBA concentrations (2000-3000 $\mathrm{mg} \mathrm{L}^{-1}$ ) do not provide any supplementary advantage. Each plant species needs an appropriate concentration of IBA to promote cell proliferation and expansion [19,36], and excessive IBA concentrations may impair development $[11,15,37]$. For instance, O. europaea needs a $3500 \mathrm{mg} \mathrm{L}^{-1}$ IBA concentration [11], and $2000 \mathrm{mg} \mathrm{L}^{-1}$ IBA induced a higher percentage of adventitious rooting in Eucalyptus benthamii [15].

Even in the absence of IBA, Fe(III)-EDDHA supplementation improves to some extent rooting (at 10 days), root biomass and number, shoot biomass, new growth and number of new shoots, and leaf photosynthetic pigment levels (at 20 days), as well as cutting survival (10 days after transplant to sand:soil mixture). The low root biomass in cuttings grown with $0 \mu \mathrm{M}$ Fe may be related to the auxin increases known to occur in Fe-deficient plants, which usually exhibit in roots morphological changes such as inhibition of elongation and swollen root tips $[21,22,38]$. The reason behind the positive effects of Fe(III)-EDDHA in the absence of IBA are not known at the current stage, although Fe is a co-factor of peroxidase, which is known to mediate the catabolism of auxin in the rooting process [38]. Evidence for 
a role of mineral nutrients (including $\mathrm{Fe}$ ) in the basal part of the cutting during rooting has been shown in Petunia $\times$ hybrida [4] and Euphorbia pulcherrima [39], as well as in the woody species Eucalyptus globulus [14], Prunus persica [26] and Pinus taeda [40]. In Petunia $\times$ hybrida leaf cuttings, it has been shown that adventitious root formation depends on the local provision of $\mathrm{Fe}$, since shoot-to-root translocation of Fe from the aerial part of the cuttings is ineffective [4]. Stimulation of adventitious root development by Fe requires auxin and involves auxin polar transport, but both the fact that spatial distribution and activity of the auxin-reporter GFP-GUS are not affected by Fe supply and the additive effect of Fe and 1-naphthaleneacetic acid suggest that Fe and auxin may have parallel mechanisms of stimulation of adventitious root formation [4].

The Fe-mediated improvements in all parameters studied are generally more marked in the presence than in the absence of IBA. These results confirm the hypothesis that supplementing IBA-treated $R$. officinalis cuttings with 5-20 $\mu \mathrm{M}$ Fe(III)-EDDHA improves rooting (at 10 days), and root biomass and number, shoot biomass and number of new shoots and the leaf levels of photosynthetic pigments (at 20 days), as well as cutting survival (10 days after transplant to sand:soil mixture). Generally speaking, the treatments including $10 \mu \mathrm{M}$ Fe and $2000 \mathrm{mg} \mathrm{L}^{-1}$ IBA appear to give adequate values for most parameters measured.

Application of Fe increased leaf photosynthetic pigment levels, in line with previous studies with other plant species [41,42], including woody ones such as Pyrus communis [43] and P. persica [44]. The increase with Fe was more marked for $\mathrm{Chl} b$ than for $\mathrm{Chl} a$ and Car, also in agreement with previous studies [43]. Iron plays roles in chlorophyll [45] and carotenoid biosynthesis [46] and is also part of many components in the chloroplast thylakoid membrane, which can be assembled only when all of them are present $[45,47]$. For instance, Calendula officinalis grown under low Fe showed decreases in Chl and Car concentrations under low Fe in the growth media [48,49]. An increase in photosynthetic pigment levels leads to higher photosynthetic rates, and therefore increases the resources for the formation and development of the root system. This would better facilitate water and nutrient uptake, therefore favouring plant survival [42,50].

In the present study, shoot new growth, number of new shoots, and shoot FW and DW were positively correlated with the root number $\left(R^{2}\right.$ values of $0.70,0.76,0.72$ and 0.64 , respectively, data not shown). This is in line with the finding that in IBA-treated Hibiscus rosa-sinensis rootstock, propagated using stenting, there was a positive correlation between shoot and root number [51]. This may be caused by a higher cytokinin generation in cuttings with a higher root number. Cytokinins are mainly synthesized in roots and transported to the shoot in the xylem transpiration stream, and they affect many aspects of plant development, including morphogenesis and shoot initiation [52,53].

\section{Conclusions}

Results indicate that the application of 5-20 $\mu \mathrm{M}$ Fe(III)-EDDHA and 1000-3000 $\mathrm{mg} \mathrm{L}^{-1}$ IBA can improve rooting, root and shoot biomass, photosynthetic pigment levels and plant survival in cuttings of the aromatic and medicinal species $R$. officinalis. These results show that the application of $\mathrm{Fe}(\mathrm{III})$-chelate during rooting can lead to the production of vigorous new plants in a shorter time. The application of this type of treatment for the propagation of other rare and valuable aromatic and medicinal plant species via cuttings would deserve further studies.

Supplementary Materials: The following supporting information can be downloaded at: https: //www.mdpi.com/article/10.3390/agriculture12020210/s1, Figure S1: Pictures of the cuttings a few days after placing them in pots with the sand:perlite mixture; Table S1: Analysis of variance (ANOVA) of morphological and biochemical traits in R. officinalis treated with different concentrations of IBA $\left(0,1000,2000\right.$ and $\left.3000 \mathrm{mg} \mathrm{L}^{-1}\right)$ at the start of the experiment and then grown with different concentrations of $\mathrm{Fe}(0,5,10$ and $20 \mu \mathrm{M})$.

Author Contributions: Design of the experiment and methodology, Z.I. and A.R.N.; data analysis, Z.I., A.R.N. and J.A.; writing—original draft preparation, Z.I., A.R.N. and J.A.; writing—review and editing, 
Z.I., A.R.N. and J.A.; supervision and project administration, A.R.N. and J.A.; and funding acquisition, A.R.N. and J.A. All authors have read and agreed to the published version of the manuscript.

Funding: The study was funded by Lorestan University, Iran. J.A. was supported by the Spanish Ministry of Science and Innovation (Grant PID2020-115856RB-100 funded by MCIN/AEI/ 10.13039/501100011033) and the Aragón Government (group A09-20R).

Conflicts of Interest: The authors declare no conflict of interest.

\section{References}

1. Hartmann, H.T.; Kester, D.E. Plant Propagation: Principles and Practices, 3rd ed.; Prentice Hall: Upper Saddle River, NJ, USA, 1975.

2. Bassuk, N.L.; Hunter, L.D.; Howard, B.H. The apparent involvement of polyphenol oxidase and phloridzin in the production of apple rooting cofactors. J. Hortic. Sci. 1981, 56, 313-322. [CrossRef]

3. Ling, W.X.; Zhong, Z. Seasonal variation in rooting of the cuttings from tetraploid locust in relation to nutrients and endogenous plant hormones of the shoot. Turk. J. Agric. For. 2010, 36, 257-266.

4. Hilo, A.; Shahinnia, F.; Druege, U.; Franken, P.; Melzer, M.; Rutten, T.; von Wirén, N.; Hajirezaei, M.-R. A specific role of iron in promoting meristematic cell division during adventitious root formation. J. Exp. Bot. 2017, 68, 4233-4247. [CrossRef] [PubMed]

5. Wu, H.C.; du Toit, E.S.; Reinhardt, C.F.; Rimando, A.M.; van der Kooy, F.; Meyer, J.J.M. The phenolic, 3,4-dihydroxybenzoic acid, is an endogenous regulator of rooting in Protea cynaroides. Plant Growth Regul. 2007, 52, 207-215. [CrossRef]

6. Epstein, E.; Lavee, S. Conversion of indole-3-butyric acid to indole-3-acetic acid by cuttings of grapevine (Vitis vinifera) and olive (Olea europaea). Plant Cell Physiol. 1984, 25, 697-703.

7. Al-Zebari, S.M.K.; Al-Brifkany, A.-A.A.M. Effect of cutting type and IBA on rooting and growth of citron (Citrus medica L). J. Exp. Agric. Int. 2015, 5, 134-138. [CrossRef]

8. Nasri, F.; Fadakar, A.; Saba, M.K.; Yousefi, B. Study of indole butyric acid (IBA) effects on cutting rooting improving some of wild genotypes of damask roses (Rosa damascena Mill.). J. Agric. Sci. 2015, 60, 263-275. [CrossRef]

9. Izadi, Z.; Zarei, H. Evaluation of propagation of chinese hibiscus (Hibiscus rosa-sinensis) through stenting method in response to different IBA concentrations and rootstocks. Am. J. Plant Sci. 2014, 5, 1836-1841. [CrossRef]

10. Peixe, A.; Raposo, A.; Lourenço, R.; Cardoso, H.; Macedo, E. Coconut water and BAP successfully replaced zeatin in olive (Olea europaea L.) micropropagation. Sci. Hortic. 2007, 113, 1-7. [CrossRef]

11. Hussain, K.; Qadri, R.; Akram, M.T.; Nisar, N.; Iqbal, A.; Yang, Y.; Khan, M.M.; Haq, I.U.; Khan, R.I.; Iqbal, M.A. Clonal propagation of olive (Olea europaea) through semi-hardwood cuttings using IBA under shaded polyethylene tunnels (SPTS). Fresenius Environ. Bull. 2020, 29, 8131-8137.

12. Shao, F.; Wang, S.; Huang, W.; Liu, Z. Effects of IBA on the rooting of branch cuttings of Chinese jujube (Zizyphus jujuba Mill.) and changes to nutrients and endogenous hormones. J. For. Res. 2017, 29, 1557-1567. [CrossRef]

13. Amini, A.; Tabari Kouchaksaraei, M.; Hosseini, S.M.; Yousefzadeh, H. Influence of Hormones Of IAA, IBA, And NAA On Improvement of rooting and early growth gf Tilia Rubra Subsp. Caucasica Form Angulata (Rupr.) V. Engler. Ecopersia 2019, 3, 169-174.

14. Schwambach, J.; Fadanelli, C.; Fett-Neto, A.G. Mineral nutrition and adventitious rooting in microcuttings of Eucalyptus globulus. Tree Physiol. 2005, 25, 487-494. [CrossRef]

15. Brondani, G.E.; Baccarin, F.J.B.; de Wit Ondas, H.W. Low temperature, IBA concentrations and optimal time for adventitious rooting of Eucalyptus benthamii mini-cutting. J. For. Res. 2012, 23, 583-592. [CrossRef]

16. Azad, M.S.; Alam, M.J.; Mollick, A.S.; Khan, M.N.I. Rooting of cuttings of the Indian almond (Sterculia foetida) enhanced by the application of the indole-3-butyric acid (IBA) under leafy and non-leafy conditions. Rhizosphere 2017, 5, 8-15. [CrossRef]

17. Vielba, J.M.; Vidal, N.; José, M.C.S.; Rico, S.; Sánchez, C. Recent advances in adventitious root formation in chestnut. Plants 2020, 9, 1543. [CrossRef]

18. Bannoud, F.; Bellini, C. Adventitious rooting in Populus species: Update and perspectives. Front. Plant Sci. 2021, 12, 918. [CrossRef]

19. Xiao, Z.; Jin, Z.; Zhang, B.; Li, F.; Yu, F.; Zhang, H.; Lu, X.; Zhang, J. Effects of IBA on rooting ability of Cinnamomum bodinieri citral type micro-shoots from transcriptomics analysis. Plant Biotechnol. Rep. 2020, 14, 467-477. [CrossRef]

20. Otiende, M.A.; Nyabundi, J.O.; Ngamau, K.; Opala, P. Effects of cutting position of rose rootstock cultivars on rooting and its relationship with mineral nutrient content and endogenous carbohydrates. Sci. Hortic. 2017, 225, 204-212. [CrossRef]

21. Marschner, H. Marschner's Mineral Nutrition of Higher Plants, 3rd ed.; Marschner, P., Ed.; Academic Press: Boston, MA, USA, 2012.

22. Landsberg, E.-C. Hormonal regulation of iron-stress response in sunflower roots: A morphological and cytological investigation. Protoplasma 1996, 194, 69-80. [CrossRef]

23. Zhu, X.F.; Wang, B.; Song, W.F.; Zheng, S.J.; Shen, R.F. Putrescine alleviates iron deficiency via NO-dependent reutilization of root cell-wall Fe in Arabidopsis. Plant Physiol. 2016, 170, 558-567. [CrossRef]

24. Johnson, C.R.; Hamilton, D.F. Effects of media and controlled-release fertilizers on rooting and leaf nutrient composition of Juniperus conferta and Ligustrum japonicum cuttings. J. Am. Soc. Hortic. Sci. 1977, 102, 320-322.

25. Ward, J.D.; Whitcomb, C.E. Nutrition of Japanese holly during propagation and production. J. Am. Soc. Hortic. Sci. 1979, $104,523-526$. 
26. Tsipouridis, C.; Thomidis, T.; Zakinthinos, Z. Iron deficiency and adventitious rooting in peach hardwood cuttings (cv. Early Crest). Austr. J. Exp. Agric. 2006, 46, 1629-1632. [CrossRef]

27. De Pasquale, C.; La Bella, S.; Cammalleri, I.; Gennaro, M.C.; Licata, M.; Leto, C.; Tuttolomondo, T. Agronomical and postharvest evaluation of the essential oils of Sicilian rosemary (Rosmarinus officinalis L.) biotypes. Acta Hortic. 2019, 1255, 139-144. [CrossRef]

28. Tuttolomondo, T.; Dugo, G.; Ruberto, G.; Leto, C.; Napoli, E.M.; Cicero, N.; Gervasi, T.; Virga, G.; Leone, R.; Licata, M.; et al. Study of quantitative and qualitative variations in essential oils of Sicilian Rosmarinus officinalis L. Nat. Prod. Res. 2015, 29, 1928-1934. [CrossRef]

29. La Bella, S.; Virga, G.; Iacuzzi, N.; Licata, M.; Sabatino, L.; Consentino, B.B.; Leto, C.; Tuttolomondo, T. Effects of irrigation, peat-alternative substrate and plant habitus on the morphological and production characteristics of Sicilian rosemary (Rosmarinus officinalis L.) biotypes grown in pot. Agriculture 2021, 11, 13. [CrossRef]

30. Gil, C.S.; Kwon, S.J.; Jeong, H.Y.; Lee, C.; Lee, O.J.; Eom, S.H. Blue light upregulates auxin signaling and stimulates root formation in irregular rooting of rosemary cuttings. Agronomy 2021, 11, 1725. [CrossRef]

31. Kiuru, P.; Muriuki, S.; Wepukhulu, S.; Muriuki, S. Influence of growth media and regulators on vegetative propagation of rosemary (Rosmarinus officinalis L.). East Afr. Agric. For. J. 2015, 81, 105-111. [CrossRef]

32. Koleva Gudeva, L.; Trajkova, F.; Mihajlov, L.; Troiciki, J. Influence of different auxins on rooting of rosemary, sage and elderberry. Ann. Res. Rev. Biol. 2017, 12, 1-8. [CrossRef]

33. Poornima, K.; Chandregowda, M.; Pushpa, T.; Srikantaprasad, D. Studies on effect of growth regulators on rooting of two rosemary types and estimation of biochemical changes associated with rooting. Crop Res. 2012, 43, $245-248$.

34. Hartmann, H.T.; Kester, D.E.; Davies, F.T., Jr.; Geneve, R.L. Plant Propagation: Principles and Practice, 7th ed.; Prentice Hall: Englewood Cliffs, NJ, USA, 2002.

35. Lichtenthaler, H.K. Chlorophylls and carotenoids: Pigments of photosynthetic biomembranes. Meth. Enzymol. 1987, 148, 350-382.

36. Björkman, T. Effect of Trichoderma colonization on auxin-mediated regulation of root elongation. Plant Growth Regul. 2004, 43, 89-92. [CrossRef]

37. Sun, W.-Q.; Bassuk, N.L. Effects of banding and IBA on rooting and budbreak in cuttings of apple rootstock 'MM. 106' and Franklinia. J. Environ. Hortic. 1991, 9, 40-43. [CrossRef]

38. Trejgell, A.; Libront, I.; Tretyn, A. The effect of Fe-EDDHA on shoot multiplication and in vitro rooting of Carlina onopordifolia Besser. Acta Physiol. Plant. 2012, 34, 2051-2055. [CrossRef]

39. Svenson, S.E.; Davies, F.T. Change in tissue mineral elemental concentration during root initiation and development of poinsettia cuttings. HortScience 1995, 30, 617-619. [CrossRef]

40. Rowe, D.B.; Blazich, F.A.; Weir, R.J. Mineral nutrient and carbohydrate status of loblolly pine during mist propagation as influenced by stock plant nitrogen fertility. HortScience 1999, 34, 1279-1285. [CrossRef]

41. Abadía, J.; Vázquez, S.; Rellán-Álvarez, R.; El-Jendoubi, H.; Abadía, A.; Álvarez-Fernández, A.; López-Millán, A.F. Towards a knowledge-based correction of iron chlorosis. Plant Physiol. Biochem. 2011, 49, 471-482. [CrossRef]

42. Briat, J.F.; Dubos, C.; Gaymard, F. Iron nutrition, biomass production, and plant product quality. Trend. Plant Sci. 2015, 20, 33-40. [CrossRef]

43. Morales, F.; Abadía, A.; Belkhodja, R.; Abadía, J. Iron-deficiency-induced changes on the photosynthetic pigment composition of field-grown pear (Pyrus communis L.) leaves. Plant Cell Environ. 1994, 17, 1153-1160. [CrossRef]

44. Abadía, J.; Tagliavini, M.; Grasa, R.; Belkhodja, R.; Abadía, A.; Sanz, M.; Faria, E.A.; Tsipouridis, C.; Marangoni, B. Using the flower Fe concentration for estimating chlorosis status in fruit tree orchards: A summary report. J. Plant Nutr. 2000, 23, $2024-2033$. [CrossRef]

45. Terry, N.; Abadía, J. Biochemistry and physiology of iron. J. Plant Nutr. 1986, 9, 609-646. [CrossRef]

46. Kim, S.H.; Ahn, Y.O.; Ahn, M.-J.; Lee, H.-S.; Kwak, S.-S. Down-regulation of $\beta$-carotene hydroxylase increases $\beta$-carotene and total carotenoids enhancing salt stress tolerance in transgenic cultured cells of sweetpotato. Phytochemistry 2012, 74, 69-78. [CrossRef]

47. Vigani, G.; Zocchi, G.; Bashir, K.; Philippar, K.; Briat, J.-F. Signals from chloroplasts and mitochondria for iron homeostasis regulation. Trends Plant Sci. 2013, 18, 305-311. [CrossRef]

48. Izadi, Z.; Rezaei Nejad, A.; Abadía, J. Physio-morphological and biochemical responses of pot marigold (Calendula officinalis L.) to split iron nutrition. Acta Physiol. Plant. 2020, 42, 6. [CrossRef]

49. Izadi, Z.; Rezaei Nejad, A.; Abadía, J. Foliar applications of thidiazuron and putrescine increase leaf iron and chlorophyll concentrations in iron-deficient pot marigold (Calendula officinalis L.). Acta Physiol. Plant. 2021, 43, 122. [CrossRef]

50. El-Jendoubi, H.; Melgar, J.C.; Álvarez-Fernández, A.; Sanz, M.; Abadía, A.; Abadía, J. Setting good practices to assess the efficiency of iron fertilizers. Plant Physiol. Biochem. 2011, 49, 483-488. [CrossRef]

51. Izadi, Z.; Zarei, H.; Alizadeh, M. Effect of time, cultivar and rootstock on success of rose propagation through stenting technique. Am. J. Plant Sci. 2014, 5, 1644-1650. [CrossRef]

52. Müller, D.; Leyser, O. Auxin, cytokinin and the control of shoot branching. Ann. Bot. 2011, 107, 1203-1212. [CrossRef]

53. Skalák, J.; Vercruyssen, L.; Claeys, H.; Hradilová, J.; Černý, M.; Novák, O.; Plačková, L.; Saiz-Fernández, I.; Skaláková, P.; Coppens, F. Multifaceted activity of cytokinin in leaf development shapes its size and structure in Arabidopsis. Plant J. 2019, 97, 805-824. [CrossRef] 